\title{
An Investigation of the Effect of Employee Empowerment on Job Performance in Ghana
}

\author{
Emmanuel Erastus Yamoah $^{1} \&$ Deborah $_{\text {Afful }}{ }^{2}$ \\ ${ }^{1}$ Senior Lecturer, School of Business, University of Education, Winneba, Ghana \\ ${ }^{2}$ Deputy Registrar, Division of Human Resources, University of Education, Winneba, Ghana \\ Correspondence: Emmanuel Erastus Yamoah, Senior Lecturer, School of Business, University of Education, \\ Winneba, Ghana. E-mail: yamoahemmle@gmail.com
}

Received: September 26, 2019

doi:10.5539/ijbm.v14n12p25

\author{
Accepted: October 28, 2019 \\ Online Published: November 8, 2019 \\ URL: https://doi.org/10.5539/ijbm.v14n12p25
}

\begin{abstract}
The primary purpose of this research was to examine the relationship between employee empowerment and job performance in Ghana. The study adopted the survey methodology to collect data from employees of selected public sector institutions across different regions of Ghana. Analysis of variance and simple regression were used to test the hypothesis in order to understand the relationships among the variables. The study found that employees who feel a high sense of empowerment in their work tend to be more effective in performing job responsibilities. Managers of organisations are encouraged to introduce empowerment programmes in their organisations for the purpose of improving job performance and enhancing competitive advantage.
\end{abstract}

Keywords: employee empowerment, public institutions, competitive advantage, job performance

\section{Introduction}

The business world today is a world of competition and enhancing the capacity of employees has become necessary for any competitive organisation in the global market. In order to keep up with the changing business environment and consumer needs, many organisations around the world have resorted to employee empowerment as a key strategic tool. Employee empowerment continue to gain increasing attention in management circles. This is because empowered employees feel capable, confident and optimistic which stimulates them to perform on the job. Empowerment programmes within organisations enable employees to be active in the decision-making process and the resultant benefits includes more creativity, high morale and boost in productivity (Paktinat \& Fathizadeh, 2008). Empowerment programmes have therefore been introduced in a number of organisations in order to improve productivity, increase customer satisfaction and enhance competitive advantage (Ergeneli, 2007; Hardy \& Leiba-O'Sullivan, 1998). A growing number of organisations recognize employee empowerment as a management technique which can be adopted to enable them cope with the needs of ever-competitive global business environment (Demitriads, 2005). Employee empowerment has been shown to influence job performance. However, there is little evidence of widespread adoption of employee empowerment practices by organisations in the developing world (Awamley, 2013). Consequently, the benefits of empowerment including higher job performance are not being realised by many organisations in the third world. It is conceivable that the relationship between employee empowerment and job performance will differ from context to context. This observation led the researchers to formulate a hypothesis in order to investigate this relationship in the Ghanaian context to understand the role empowerment plays in job performance.

\subsection{Hypothesis}

$\mathrm{H}_{\mathrm{ol}}$ : There is no statistically significant relationship between employee empowerment and job performance.

\section{Literature Review}

\subsection{The Concept of Empowerment}

The concept of employee empowerment has been discussed extensively due to its relevance to organisational and management researchers and practitioners. Notwithstanding all the recognition given employee empowerment in business and academia, there is little agreement among either scholars or practitioners as to the exact nature of the empowerment construct (Roller, 1998). Lawler (1992) defined empowerment as a set of managerial practices 
aimed at increasing an employee's autonomy and responsibilities thereby enabling them to discharge their job or tasks more effectively and efficiently. Empowerment also means the capacity to do things; it means to be able to do (Gibson, 1991). Employees who feel strong empowerment have qualities, which make possible a strong sense of self-respect, outstanding professional performance and progress in their work (Suminen, 2005). Empowerment also means to give power to an individual. This can mean a number of things. In the literal meaning, power is equal with the word authority and empowerment therefore means authorisation (Grönfeldt \& Strother, 2006). Power also may be used to describe capacity or competence which means that one has the necessary skills and abilities to perform a job well (Conger \& Kanungo, 2008). Furthermore, power also implies energy and thus to empower can also mean to energize (Hardy \& Leiba-O'Sullivan, 1998). As a theoretical construct, employee empowerment cannot be measured directly in real setting but only through observation of related phenomena. Roller (1998) argued that certain facets of empowerment construct can be identified and measured. These features relate to individual perceptions of self-control, control of one's environment, and personal commitment. The Perception of Empowerment Instrument has been developed to measure specific behaviours associated with individual empowerment (Roller, 1998).

\subsection{Perception of Empowerment Instrument (PEI)}

The Perception of Empowerment Instrument (PEI) was developed by Roller (1998). An effective and useful assessment scale measures a construct by assessing specific behaviours that are inferred from the content of the construct. Theoretical concepts that cannot be measured directly in a real setting are referred to as theoretical constructs (Roller, 1998). Empowerment is a theoretical construct. As a construct, it cannot be measured directly, but only through the observation of related phenomena. It is important that theoretical concepts be related to sensory impressions in concrete situations. The Perception of Empowerment Instrument measures specific behaviours associated with individual empowerment (Roller, 1998). The Perception of Empowerment Instrument expands the limited amount of work that has been done in an attempt to identify and measure the dimensions of empowerment. The PEI measures empowerment dimensions that are less abstract and more behaviourally specific than those included in any previously validated measure of the construct. The three dimensions measured by the Perception of Empowerment Instrument are more concrete representations of the empowerment dimensions measured by previous assessment scales (Roller, 1998). These dimensions are autonomy, participation, and responsibility.

The dimension of individual empowerment referred to as autonomy in the Perception of Empowerment Instrument refers to an individual's perception of the level of freedom and personal control that he or she possesses and is able to exercise in the performance of his or her job (Roller, 1998). Participation dimension refers to an individual's perception of his or her influence in producing desired effects in his or her environment. It represents the degree to which an individual feel that he or she has input into their organisation's administrative or strategic decisions. Individual participation in organizational decision making is an important dimension of individual empowerment. Individual employees cannot become empowered unless they are encouraged to participate fully in developing and improving organisational processes (Roller, 1998). Responsibility dimension is related to the level of concern, care, commitment or responsibility that an individual brings to a task or position, and to a feeling of psychological investment that produces commitment and energy. Roller (1998) argued that empowered employees exhibit commitment, ownership, and responsibility regarding the jobs they do and the outcomes of the decisions they make.

\subsection{Job Performance}

According to Rotundo (2002), job performance is an important dependent variable which is of interest to researchers, businesses and governments. Researchers and businesses have postulated on common definitions and conceptualizations of individual level job performance. Rotundo (2000) explained that although researchers provide their own conceptualization of job performance, a typical definition focuses on behaviours or actions of individuals, not results or outcomes of these actions and behaviours. Murphy (1993) stated that job performance should be defined in terms of behaviours rather than results. He explained that results-based measures are not always functional to the organisation, as employees may try to maximize results at the expense of other things. In the job of a retail sales clerk, examples of behaviours include greeting customers, answering questions about store products, demonstrating knowledge of store policy and procedures, where an example of a results measure includes total sales per week or month. In a situation where employees are evaluated on sales only, employees may compromise certain behaviours (being polite to customers) in order to try to maximize sales (e.g., forcing products on customers). Murphy also defined performance as behaviours that are related to the goals of the organisation. Campbell et al. (1990) defined performance as those actions or behaviours under the control of the individual, that contribute to the organisation's goals, and that can be measured according to the individual's 
level of proficiency, a definition that is consistent with the others.

The definitions of job performance reviewed here have some common features. These features include a focus on behaviours that are under the control of individual not results and on behaviours that contribute to the goals of the organisation. Job performance needs to be differentiated from other measures of performance that are sometimes used interchangeably, often incorrectly so. Unlike performance, which focuses on actions and behaviours, Campbell (1990) defined individual effectiveness as an evaluation of the results of an action. For example, evaluating the total sales of a retail sales clerk at the end of the day or month against the standards of performance for sales clerks set by the store is an example of a measure of effectiveness, where a measure that rates the sales clerk on appropriate work behaviours is a measure of job performance. Although effectiveness is sometimes used as an index of job performance, it actually measures something different (Campbell et al. 1990).

\subsection{Employee Empowerment and Job Performance}

The role of empowerment in improving employees' performance has well been established in many ways. Awamleh (2013) studied 500 employees using descriptive-analytic approach and found a clear link between empowerment and job performance. He stated that empowerment plays significant role in employee's satisfaction thus promoting their performance in organisations. Employee's participation in decision making, delegation of power, access to information and resources and job enrichment are common forms and tools of empowerments. Similar finding was reported by Said (2010), whose results also showed statistically significant positive relationships between employees' empowerment and job satisfaction.

Klidas et al. (2011) conducted a survey of employees of 15 hotels in 7 different European countries and reported that stimulating empowerment in employees lead to attainment of targeted goals. Yans and Choi (2012), Wang and Lee (2009) also found significant relationship between empowerment and job performance. Sarkissian (2015) stated that empowered employees are an important factor in the long-term success of any organisation. Empowerment improves all aspects of employees' performance. Washington (2012) studied the effect of empowerment on task, organisational citizenship and counterproductive behaviour. His findings confirmed significant relationship between empowerment and all the three measures of job performance. Authors such as Spreitzer (2005), Thomas and Fieldman (2009), confirmed the effect of psychological empowerment on job performance. If employees feel good about their job and also if the organisation allows employees to make decisions and provide the flexibility, all these factors are likely to increase their job performance (Chiang \& Hsieh, 2012).

Menon (1995) surveyed 311 employees of a company to determine the effects of empowerment on the employees and found that greater job autonomy and the meaningfulness of the job had a positive relationship with perceived control and empowerment. Moreover, this finding presents the idea that greater empowerment leads to higher satisfaction of the individual with his or her job. Other studies have examined more closely the effects of empowerment on sub-categories of employee performance. Washington (2012) investigated the effect of psychological empowerment on task performance, organisational citizenship behaviour, and counterproductive work behaviour. He obtained results which confirmed that empowerment significantly influences individuals' task, citizenship and counterproductive behaviour.

\section{Methodology}

The study design was descriptive survey. The researchers considered the survey research design appropriate for this study because all the variables of the study were observed at a point in time. Using structured questionnaire as the research instrument, the researchers collected data on employee empowerment and job performance in order to investigate the relationships among the variables. The targeted population was all employees of 5 public sector institutions in Ghana. A total of 400 questionnaires were printed and distributed to the respondents using convenience sampling technique. 332 respondents representing $83 \%$ of the total number returned the completed questionnaire. Employee empowerment was measured with 12 items adapted from Roller (1998) 'The Perception of Empowerment Instrument' with Cronbach's alpha mean of the responses as of 0.866. The items of job performance (dependent variable) were adapted from Johari (2012). Johari obtained Cronbach's alpha of 0.937 for overall job performance. Nunnaly $(1978$, p. 24) recommended that "instruments used in basic research should have a reliability of about 0.70 or better." The simple regression equation was used to estimate the effect of employee empowerment on job performance. Hypothesis resulting in test statistics with $\mathrm{p} \leq .05$ was rejected.

Regression Model:

$$
\operatorname{Perf}_{i}=\beta_{0}+\beta_{1} E_{m p}+u_{i}
$$




\section{Results and Discussion}

\subsection{Employees' Perception of Empowerment}

The result obtained on the employees' perception of empowerment at their workplaces is presented in table 1.

Table 1. Perception of empowerment frequencies, percentages, and mean of responses

\begin{tabular}{|c|c|c|c|c|c|c|}
\hline Scale Items & $\mathbf{N}$ & $\begin{array}{l}\text { Strongly } \\
\text { Disagree } \\
(\%)\end{array}$ & $\begin{array}{l}\text { Disagree } \\
(\%)\end{array}$ & $\begin{array}{l}\text { Agree } \\
(\%) \\
\end{array}$ & $\begin{array}{l}\text { Strongly } \\
\text { Agree } \\
(\%) \\
\end{array}$ & Mean \\
\hline I have the freedom to decide how to do my job & 321 & $\begin{array}{l}16 \\
(4.8)\end{array}$ & $\begin{array}{l}13 \\
(3.9)\end{array}$ & $\begin{array}{l}281 \\
(84.6)\end{array}$ & $\begin{array}{l}11 \\
(3.3)\end{array}$ & 2.8941 \\
\hline I am often involved when changes are planned & 332 & - & $\begin{array}{l}32 \\
(9.6)\end{array}$ & $\begin{array}{l}286 \\
(86.1)\end{array}$ & $\begin{array}{l}14 \\
(4.2)\end{array}$ & 2.9458 \\
\hline I can be creative in finding solutions to problems & 332 & - & $\begin{array}{l}1 \\
(0.3)\end{array}$ & $\begin{array}{l}248 \\
(74.7)\end{array}$ & $\begin{array}{l}83 \\
(25.0)\end{array}$ & 3.2470 \\
\hline $\begin{array}{l}\text { I am involved in determining organisational } \\
\text { goals }\end{array}$ & 332 & $\begin{array}{l}6 \\
(1.8)\end{array}$ & $\begin{array}{l}25 \\
(7.5)\end{array}$ & $\begin{array}{l}219 \\
(66.0)\end{array}$ & $\begin{array}{l}82 \\
(24.7)\end{array}$ & 3.1355 \\
\hline I am responsible for the results of my decisions & 332 & - & $\begin{array}{l}1 \\
(0.3)\end{array}$ & $\begin{array}{l}280 \\
(84.3)\end{array}$ & $\begin{array}{l}51 \\
(15.4)\end{array}$ & 3.1476 \\
\hline I take responsibility for what I do & 332 & $\begin{array}{l}11 \\
(3.3)\end{array}$ & $\begin{array}{l}2 \\
(0.6)\end{array}$ & $\begin{array}{l}262 \\
(78.9)\end{array}$ & $\begin{array}{l}57 \\
(17.2)\end{array}$ & 3.0994 \\
\hline I am responsible for the outcomes of my actions & 326 & $\begin{array}{l}1 \\
(0.3)\end{array}$ & $\begin{array}{l}230 \\
(69.3)\end{array}$ & $\begin{array}{l}90 \\
(27.1)\end{array}$ & $\begin{array}{l}5 \\
(1.5)\end{array}$ & 3.7301 \\
\hline I am personally responsible for the work I do & 332 & - & $\begin{array}{l}150 \\
(45.2)\end{array}$ & $\begin{array}{l}182 \\
(54.8)\end{array}$ & - & 3.5482 \\
\hline I am involved in decisions that affect me & 332 & - & $\begin{array}{l}27 \\
(8.1)\end{array}$ & $\begin{array}{l}216 \\
(65.1)\end{array}$ & $\begin{array}{l}89 \\
(26.8)\end{array}$ & 3.1867 \\
\hline $\begin{array}{l}\text { I make my own decisions about how to do my } \\
\text { work }\end{array}$ & 326 & - & $\begin{array}{l}16 \\
(4.9)\end{array}$ & $\begin{array}{l}241 \\
(73.9)\end{array}$ & $\begin{array}{l}69 \\
(21.2)\end{array}$ & 3.1626 \\
\hline I am involved in creating our vision of the future & 326 & - & $\begin{array}{l}38 \\
(11.2)\end{array}$ & $\begin{array}{l}254 \\
(78.3)\end{array}$ & $\begin{array}{l}34 \\
(10.4)\end{array}$ & 2.9908 \\
\hline My ideas and inputs are valued & 331 & $\begin{array}{l}6 \\
(1.8)\end{array}$ & $\begin{array}{l}67 \\
(20.2)\end{array}$ & $\begin{array}{l}196 \\
(59.0)\end{array}$ & $\begin{array}{l}62 \\
(18.7)\end{array}$ & 2.9486 \\
\hline Grand Mean & & & & & & 3.1621 \\
\hline
\end{tabular}

Empowerment practices in the public sector organisations were assessed. The result on respondents' view on having freedom to decide how to do their job indicated that $11(3.3 \%)$ strongly agreed, 281(84.6\%) agreed, 13 (3.9\%) disagreed and $16(4.8 \%)$ strongly disagreed. 32(9.6\%) disagreed with the statement that they are 'often involved when changes are planned'. However, 286 people representing $86.1 \%$ and 14 individuals representing $4.2 \%$ agreed and strongly agreed respectively to the statement. Only $1(0.3 \%)$ respondent disagreed with the statement that they can be creative in finding solutions to problems, 248(74.7\%) agreed and 83(25\%) strongly agreed. Two thirds $(66 \%)$ of the respondents agreed that they are involved in determining organisational goals, $24.7 \%$ strongly agreed. On the other hand, $1.8 \%$ strongly disagreed and $7.5 \%$ disagreed to being involved in determining organisational goals.

Respondents' opinion was sought on the statement that they take responsibility for their work, the result indicates that $11(3.3 \%)$ strongly disagreed, $2(0.6 \%)$ disagreed, $262(78.9 \%)$ agreed and $57(17.2 \%)$ strongly agreed. On their involvement in decisions that affect them, the result indicates that $89(26.8 \%)$ strongly agreed, $216(73.9 \%)$ agreed and $27(8.1 \%)$ disagreed. None of the respondents strongly disagreed with the statement on their involvement in decisions that affect them. Majority of the respondents $(73.9 \%)$ agreed that they make their own decisions about how to do their work, $21.2 \%$ strongly agreed and $4.9 \%$ disagreed. Respondents' view on their involvement in creating a vision of the future for their organisations, the result indicates that $38(11.2 \%)$ disagreed, $254(78.3 \%)$ agreed and $34(10.4 \%)$ strongly agreed. The result also indicates that $62(18.7 \%)$ strongly agreed and $196(59 \%)$ agreed to the statement that their ideas and inputs are valued in their organisations. However, $6(1.8 \%)$ and 67 (20.2\%) strongly disagreed and disagreed respectively that their ideas and inputs are valued. 
The analysis of the result in Table 1 indicates the existence of strong empowerment practices (mean=3.1621) in the selected public sector organisations.

\subsection{Testing of Hypothesis}

The study hypothesis states that no statistically significant relationship would be detected between employee empowerment and job performance. The results of the tests are presented in tables 2 and 3.

Table 2. ANOVA - Employee empowerment and job performance

\begin{tabular}{llllll}
\hline Source & ss & df & ms & F & Sig. \\
\hline Model & 1.1788 & 1 & 1.178 & 8.21 & 0.0046 \\
Residual & 29.143 & 319 & 0.143 & & \\
Total & 30.32 & 320 & 0.148 & & \\
\hline
\end{tabular}

Note. Predictors: Empowerment.

Dependent variable=Job Performance.

Table 3. Employee empowerment and job performance

\begin{tabular}{lllll}
\hline Model & Coefficient & Standard error & t & Sig. \\
\hline Empowerment & 0.153 & 0.053 & 2.87 & 0.005 \\
Constant & 0.575 & 0.089 & 6.45 & 0.000 \\
\hline
\end{tabular}

Note. R-Squared $=0.0389$;

R-Squared adjusted $=0.0341$;

Dependent Variable $=$ Job Performance.

Table 2 is the analysis of variation of employee empowerment on job performance. This test as suggested by the $\mathrm{F}$ test shows that empowerment affects performance $\left(F_{1,319}=8.21, p>F=0.0046\right)$. This is followed by a simple regression of empowerment on performance (see table 3). As expected, we found a significant positive relationship between empowerment and performance. An increase in empowerment by one unit increases an employee's performance by 0.153 units. The coefficient of determination (R-squared) is about $4 \%$. This implies that empowerment alone explains about $4 \%$ of the changes in job performance.

\subsection{Discussion of Findings}

This study investigated the relationship between employee empowerment and job performance. On a five-point scale the respondents' overall rating of empowerment practices in their organisations was above average $(m e a n=3.1621)$. The result of the regression analysis indicated that the relationship between empowerment and performance was significant $\left(\mathrm{R}^{2}=0.118 ; \mathrm{p}=0.000 ; \mathrm{p}<0.05\right)$. This result is consistent with earlier studies done on the same subject. Chebet (2013) studied employees' empowerment and job performance and reported significant positive correlation between the variables. The result of the test of the hypothesis was a Pearson correlation coefficient $=0.484, \mathrm{df}=1$ which was significant at $\mathrm{p}=.000(\mathrm{p}<0.05)$. Sarkissian $(2015)$ and Wang and Lee (2009) reported similar findings. Wang and Lee's regression analysis show that empowerment is positively related to job performance $(\mathrm{t}=2.37, \mathrm{p}<0.05)$. The result indicated that when empowerment increases, employees' performance also increases. The beta coefficient for empowerment was significant $(\beta=0.73, p<$ 0.05 ), indicating a direct and positive relationship between empowerment and employees' performance. The coefficient of determination $\left(\mathrm{R}^{2}\right)$ was 0.37 . This means empowerment accounted for $37 \%$ of the variance of employees' performance. Sarkissian concluded that empowering employees positively impacts on job performance. Manu (2004) and Liao and Chuang (2004) found that empowerment played significant role in service employees' satisfaction and job performance. They posited further that empowerment give managers the opportunity to move away from telling employees exactly how to solve a problem, and rather provide employees with guidance necessary for long-term growth and performance improvement.

The hypothesis which states that there is no statistically significant relationship between empowerment and job performance is rejected $\left(\mathrm{R}^{2}=0.118 ; \mathrm{p}=0.000\right)$.

\section{Conclusion and Managerial Implications}

In an era of globalization and increasing competitiveness in the marketplace, there is need for employee 
empowerment in organisations so that employees will be in position to make quick decisions and respond quickly to any changes in the environment. Employee empowerment can serve as a motivational technique if organisations design and implement empowerment programmes effectively. Furthermore, when properly implemented, employee empowerment would serve as an innovative approach in shifting power from top management control to lower level management of the organisation. Organisations that are committed to employees' empowerment are in position to also motivate and retain their employees. Managers of organisations are encouraged to introduce empowerment programmes in their organisations in order to improve job performance and enhance their competitive advantage.

\section{References}

Awamley, N. (2013). Enhancing employees' performance via empowerment: A field survey. Asian Journal of Business Management, 5(3), 313-319. https://doi.org/10.19026/ajbm.5.5328

Campbell, J. P., McHenry, J. J., \& Wise, L. L. (1990). Modeling job performance in a population of jobs. Personnel Psychology, 43(2), 313-333. https://doi.org/10.1111/j.1744-6570.1990.tb01561.x

Chien, M. (2015). A study to improve organizational citizenship behaviors. Retrieved from http://www.mssanz.org.au/MODSIM03.

Conger, J. A., \& Kanungo, R. N. (2008). The empowerment process: integrating theory and practice. Academy of Management Review, 83(3), 273-284.

Demitriades, S. (2005). Employee empowerment in the Greek context. International Journal of Manpower, 26, 80-92. https://doi.org/10.1108/01437720510587299

Ergeneli, A. (2007). Psychological empowerment and its relationship to trust immediate Managers. Journal of Business Research, 60, 41-49. https://doi.org/10.1016/j.jbusres.2006.09.012

Gibson, C. (1991). Concept analysis of empowerment. Journal of Advanced Nursing, 16, 354-361. https://doi.org/10.1111/j.1365-2648.1991.tb01660.x

Giddens, A. (1984). The constitution of society. Cambridge: Polity.

Grönfeldt \& Strother. (2006). Service leadership: The quest for competitive advantage. London: SAGE Publications Inc.

Hardy, C., \& Leiba-O'Sullivan, S. (1998). The power behind empowerment: implications for research and practice. Human Relation, 51, 451-483. https://doi.org/10.1177/001872679805100402

Johari, J. (2012). An Assessment of the reliability and validity of job performance Measurement. Journal of Pengurasan, 36, 17-31. https://doi.org/10.17576/pengurusan-2012-36-02

Klidas, A., Van den Berg, P. T. \& Wilderom, C. P. M. (2011). Managing employee empowerment in luxury hotels in Europe, International Journal of Service Industry, 18 (1), 143-156. https://doi.org/10.1108/09564230710732902

Lawler, E. E. (1992). The ultimate advantage: creating the high involvement organization. San Francisco: Jossey-Bass.

Liao, H., \& Chuang, A. (2004). A multilevel investigation of factors influencing employee service performance and customer outcomes, Academy of Management, 47(1), 41-58. https://doi.org/10.2307/20159559

Manu, S. (2004). Training and development techniques for improving organisational performance for Ghana firms. Unpublished Master of Science Thesis, University of Wisconsin - Stout.

Menon, S. T. (1995). Empowerment: definition, measurement and construct validation. Montreal: McGill University, Canada.

Murphy, K. R. (1993). Honesty in the Workplace. Belmont, CA: Brooks/Cole.

Nunnaly, J. C. (1978). Psychometric theory. New York: McGraw-Hill.

Paktinat, E., \& Fathizadeh, A. (2008). Empowerment of employees: Requirements and solutions. Journal of Management Research, 11, 47-33.

Roller W. K. (1998). The Perception of empowerment instrument. Retrieved from Nhqualitycampaign.org/21/05/16. 
Rotundo, M. (2000). The relative importance of task, citizenship, and counterproductive performance to global ratings of job performance: A policy-capturing approach. Dissertation Abstracts International, 61(5-A). https://doi.org/10.1037/0021-9010.87.1.66

Rotundo, M. (2002). Defining and measuring individual level job performance: A review and integration. Retrieved from http://citeseerx.ist.psu.edu

Rotundo, M., \& Sackett, P. R. (2002). The relative importance of task, citizenship, and counterproductive performance to global ratings of job performance: A policy capturing approach. Journal of Applied Psychology, 87(1), 66-80.

Sarkissian, A. (2015). How does empowerment affect employee performance? Houston: Hearst Publications.

Spreitzer, G. M., Kizilos, M. A., \& Nason, S. W. (2005). A dimensional analysis of the relationship between psychological empowerment and effectiveness, satisfaction and strain. Journal of Management, 23(5), 679-704. https://doi.org/10.1177/014920639702300504

Suminen, T. (2005). Work empowerment as experienced by head nurses. Journal of Nursing Management, 13, 147-153. https://doi.org/10.1111/j.1365-2934.2004.00523.x

Thomas, W., \& Fieldman, D. (2009). How broadly does education contribute to job performance? Personnel Psychology, 62, 89-134. https://doi.org/10.1111/j.1744-6570.2008.01130.x

Wang, G., \& Lee, P. D. (2009). Psychological empowerment and job satisfaction An analysis of interactive effects, Group \& Organization Management, 34(3), 271-296. https://doi.org/10.1177/1059601108330089

Washington, D. A. (2012). The moderating effect of psychological empowerment on the relationship between network centrality and individual job performance. Unpublished Master Thesis, AIR University.

Yang, S., \& Choi, S. O. (2009). Employee empowerment and team performance: Autonomy, responsibility, information, and creativity. Team Performance Management: An International Journal, 15(5/6), $289-301$. https://doi.org/10.1108/13527590910983549

\section{Copyrights}

Copyright for this article is retained by the author(s), with first publication rights granted to the journal.

This is an open-access article distributed under the terms and conditions of the Creative Commons Attribution license (http://creativecommons.org/licenses/by/4.0/). 